\title{
Brice Pitt—in memoriam
}

\author{
John Cox ${ }^{1}$ \\ Published online: 29 June 2021 \\ (c) The Author(s), under exclusive licence to Springer-Verlag GmbH Austria, part of Springer Nature 2021
}

Brice Pitt died in London from COVID-19 on Jan. 16, 2021, aged 89 years. Brice made a fundamental contribution to the origins of the Marcé Society. He was its sixth president, and if not present in reality at the 1980 Manchester conference when the Society was founded, he occupied a virtual space since none of us researching the non-psychotic mood disorders or the Blues at that time would have failed to mention his seminal 1968 paper in any responsible presentation. Indeed, for myself, his finding that one in ten of new mothers had a depressive disorder which he called 'atypical depression' was the spur to my transcultural studies in Uganda. Brice helped to welcome us back to the London Hospital as a colleague whose integrative approach to psychiatry had been formative.

What can we learn and try to emulate from Brice's vision and his modus vivendi? To an extent, he was larger than life. He directed a semi-professional theatre company, wrote with ease, directed the Royal College of Psychiatrists Education Committee and chaired the Defeat depression Campaign. He became a much-respected Professor of Old Age psychiatry. Witing a popular text book in this field which has had five reprints, as well as a classic Royal College publication Down with Gloom.

Listen to health visitors (they suggested his research) as they point you to what is presently unknown, and know the mental disorders that can strike young families.

Think family and be aware of the burden of mental health disorders on cross-generational misunderstandings.

Do not shrink from personal disclosure-when appropriate.

Maintain creativity. Use the insights of the Arts to assist with the understanding, and absorption of, compassionate empathy - but also stick close to scientific method and know the evidence base for clinical options.

Maintain institutional memory and collegial friendships.

Consider 'Blue Skies' research on a small budget.

In an interview with Jane Hanley in his home, he said he was proud to be president of the first User Group-the Association of Post-natal Illness which he had initiated. He was also pleased and surprised that the Marcé Society was doing so well!

Brice like myself was from 'The London Hospital' stable in Whitechapel and was assisted by consultant psychiatrists working at the London at that time. He too worked with Desmond Pond and with a child psychiatrist Sttephen Wolkind on parent infant relationships.

Brice Pitt's legacy to the Marcé Society and to perinatal psychiatry as a whole was not only his scientific findings of critical importance but also his wholesome values, blending arts and science, and enabling the society to become more multi-professional and more inclusive of women's voices.

His later work in Old Age Psychiatry may prompt the thought that the sowing of seeds, being seminal, not only leads to growth and personal development but also to the fulfilment of older age which heralds endings and yet also the recycling of life.

John Cox.

Cheltenham March 2021.

Publisher's Note Springer Nature remains neutral with regard to jurisdictional claims in published maps and institutional affiliations.
John Cox

john6.cox@gmail.com

1 Keele University, Staffordshire ST5 5BG, UK 